\title{
A Decade of Herbicide-Resistant Crops in Canada
}

\author{
H. J. Beckie ${ }^{1}$, K. N. Harker ${ }^{2}$, L. M. Hall ${ }^{3}$, S. I. Warwick ${ }^{4}$, A. Légère ${ }^{1}$, P. H. Sikkema ${ }^{5}$, G. W. \\ Clayton $^{2}$, A. G. Thomas ${ }^{1}$, J. Y. Leeson ${ }^{1}$, G. Séguin-Swartz ${ }^{1}$, and M.-J. Simard ${ }^{6}$ \\ ${ }^{1}$ Agriculture and Agri-Food Canada (AAFC), Saskatoon, SK; ${ }^{2}$ AAFC, Lacombe, AB; ${ }^{3}$ Alberta \\ Agriculture, Food and Rural Development/University of Alberta, Edmonton, AB; ${ }^{4} \mathrm{AAFC}$, \\ Ottawa, ON; ${ }^{5}$ Ridgetown College, Ridgetown, ON; ${ }^{6} \mathrm{AAFC}$, Sainte-Foy, QC.
}

Key words: Canola, Brassica napus, corn, Zea mays, soybean, Glycine max, wheat, Triticum aestivum, gene flow, herbicide resistance, transgenic crop, volunteer crop

\begin{abstract}
This review examines some agronomic, economic, and environmental impacts of herbicideresistant (HR) canola, soybean, corn, and wheat in Canada after 10 years of growing HR cultivars. The rapid adoption of HR canola and soybean suggests a net economic benefit to farmers. HR crops often have improved weed management, greater yields or economic returns, and similar or reduced environmental impact compared with their non-HR crop counterparts. There are no marked changes in volunteer weed problems associated with these crops, except in zero-tillage systems when glyphosate is used alone to control canola volunteers. Although gene flow from glyphosate-HR canola to indigenous populations of bird's rape in eastern Canada has been measured, enrichment of hybrid plants in such populations should only occur when and where herbicide selection pressure is applied. Weed shifts as a consequence of HR canola have been documented, but a reduction in weed species diversity has not been demonstrated. Reliance on HR crops in rotations using the same mode-of-action-herbicide and/or multiple in-crop herbicide applications over time can result in intense selection pressure for weed resistance and consequently, greater herbicide use in the future to control HR weed biotypes. History has repeatedly shown that cropping system diversity is the pillar of sustainable agriculture; stewardship of HR crops must adhere to this fundamental principle.
\end{abstract}

\section{Introduction}

Globally, resistance to non-selective herbicides (i.e., glyphosate, GLY; glufosinate, GLU) is the dominant type of transgenic crop ( $71 \%$, stacked traits excluded), and cultivated area has continued to expand since 1995 (Table 1). Herbicide-resistant (HR) soybean [Glycine max (L.) Merr.] comprises the largest area at 54.4 million ha or $60 \%$ of the area planted to transgenic crops. Other important transgenic-HR crops include corn/maize (Zea mays L.) (11\% by area), cotton (Gossypium hirsutum L.) (5\%), and canola (Brassica napus L.) (5\%). World-wide, $60 \%$ of soybean, $18 \%$ of canola, $14 \%$ of cotton, and $7 \%$ of corn planted in 2004 were transgenic HR cultivars. Canada is the fourth largest producer of transgenic-HR crops, after the United States, Argentina, and Brazil (James 2005).

Four HR field crops are registered in Canada (Table 2): canola (denotes Argentine canola or spring oilseed rape in the remainder of the paper), soybean, corn, and wheat (Triticum aestivum 
L.). Canola and spring wheat are grown predominantly in western Canada, whereas soybean and corn are mostly grown in eastern Canada. Among these HR crops, canola occupies over $80 \%$ of the cultivated area, followed by soybean, corn, and wheat.

This review examines some agronomic, economic, and environmental impacts of HR canola, soybean, corn, and wheat in Canada after 10 years of growing HR cultivars.

\section{Adoption of Herbicide-Resistant Crops}

Transgenic-HR canola was introduced commercially in Canada in 1995. Of the approximately 5.5 million ha of canola grown in 2005 (Statistics Canada 2005), about 95\% (5.2 million ha) is estimated to be resistant to GLY, GLU, or IMI (Figure 1). Eighty-two percent of HR canola is transgenic. Cultivation of the crop in eastern Canada accounts for only $0.6 \%$ of the nation's canola area. In 1997, the number of non-HR canola cultivars commercially available peaked at 46, compared with only seven HR cultivars (Anonymous 1995-2005). By 2005, there were only two non-HR cultivars and 43 private-sector HR cultivars (28 GLY-HR, 11 IMI-HR, 4 GLU-HR). Public institutions have an important role in ensuring non-HR cultivars, which have similar agronomic performance as HR cultivars, continue to be available to farmers.

Similar to canola, adoption of HR soybean has been rapid. All registered HR cultivars are resistant to GLY (Table 2). Eighty percent of the Canadian soybean crop is grown in Ontario (Statistics Canada 2005). GLY-HR soybean was first grown in 1997, and now constitutes about $55 \%(518,000 \mathrm{ha})$ of the total crop area in that province (Figure 2). In contrast to soybean, adoption of HR corn has been less rapid. Fifty-seven and 34\% of corn in Canada is grown in Ontario and Québec, respectively (Statistics Canada 2005). HR corn cultivars were first grown in 1998 (Beckie et al. 2001b). In 2005, GLU-HR and GLY-HR corn comprised 14 and 12\%, respectively, of the crop area in Ontario; 23 and 27\%, respectively, of the crop area in Québec; and 17 and $18 \%$, respectively, of the total crop area in eastern Canada (M. Gans, pers. comm.). The total area of transgenic-HR corn in Canada in 2005 was 485,000 ha. Less rapid adoption of HR corn than HR soybean reflects the performance and cost of herbicide treatments in non-HR corn.

In 2004, 'CDC Imagine' was the first IMI-HR spring wheat cultivar grown commercially. The cultivar was not listed in the 2004 Canadian Wheat Board variety survey (CWB 2004), indicating that the planted area was exceedingly small. Limited seed available to producers that year may have contributed to the small cultivated area. In 2005, the planted area of IMI-HR wheat in the prairies was estimated at 81,000 ha (M. Munro; S. Pratt, pers. comm.) or $1 \%$ of the total area planted to spring wheat. The 2005 Canadian Wheat Board variety survey lists CDC Imagine at $1.3 \%$ of the area planted in the prairies to Canada Western Red Spring wheat cultivars, ranging from $0.3 \%$ in Manitoba to $1.6 \%$ in Saskatchewan (CWB 2005).

The rapid rate of adoption of some HR crops, such as canola and soybean, suggests a net economic benefit to farmers. Adoption of HR crops is driven primarily by easier and improved weed control or higher net returns (Devine and Buth 2001). Herbicides used in such crops can generally be applied over a wide range of crop growth stages with little potential injury. HR crops have facilitated the adoption of conservation-tillage systems (and vice versa) by use of 
postemergence (POST)-applied herbicides vs. preemergence (PRE) soil-incorporated herbicides, such as metolachor or ethalfluralin, which are commonly used in some non-HR crops.

\section{Herbicide-Resistant Crop Productivity and Quality}

HR canola cultivars that were initially released were slightly inferior in yield or quality to nonHR cultivars (Stringam et al. 2003). Private breeding efforts were increased by the development of marketable HR traits and the introduction of hybrid cultivars, which provided some measure of trait protection as well as yield and agronomic improvement. As a result, HR cultivars now yield the same or greater than non-HR cultivars and have equal quality (Stringam et al. 2003). A survey in 2000 commissioned by the Canola Council of Canada (Serecon Management Consulting Inc. and Koch Paul Associates 2001) of HR (GLY or GLU) and non-HR canola producers indicated that yields of HR cultivars averaged about $10 \%$ more than non-HR cultivars ( 1.7 vs. $\left.1.5 \mathrm{t} \mathrm{ha}^{-1}\right)$. The greater yields of HR cultivars were attributed to higher yield potential and reduced weed competition. Similar results were reported by Harker et al. (2000); yields of HR canola were greater when treated with GLY, GLU, or IMI than herbicides typically used in non-HR canola, particularly when difficult-to-control weed populations were present. Yields are often similar among GLY, GLU, and IMI-HR canola systems (Clayton et al. 2004a, b; Harker et al. 2004). Breeding efforts focused almost exclusively on HR germplasm will likely further widen the yield gap with non-HR canola.

In a survey of seedlot samples from registration plot trials and commercial fields, GLY- and GLU-HR canola had improved seed quality with slightly greater oil content, and significantly less glucosinolates and chlorophyll content than non-transgenic canola (Daun 2004). In transgenic canola seedlots, lower glucosinolate levels were attributed to decreased contamination by cruciferous weeds, such as wild mustard, whereas more even and earlier maturation due to improved field management linked to the HR trait was a possible reason for the reduced chlorophyll content.

In contrast to HR canola, soybean variety trials in Ontario continue to show that non-GLY-HR cultivars often yield better than their GLY-HR counterparts (Bohner 2003; OOPSCC 2005). The slight (about $4 \%$ on average) yield advantage of non-GLY-HR vs. GLY-HR soybean (Table 3 ) has been attributed mainly to differences in cultivar genetics; germplasm used in breeding GLYHR soybean was not well adapted for Ontario. Despite the lower mean yield potential of GLYHR than non-GLY-HR soybean, yields in commercial fields of GLY-HR soybean can be similar or even greater than those in non-HR soybean fields as a result of improved weed control (Bohner 2003).

Unlike soybean, there is no consistent yield difference between HR (GLY, GLU) and non-HR corn hybrids (Table 4). The majority of hybrids are non-HR. Both HR and non-HR hybrids may possess the Bacillus thuringiensis $(\mathrm{Bt})$ trait for protection against the European corn borer.

Yield of the IMI-HR cultivar CDC Imagine is similar to 'AC Barrie', the standard hard red cultivar, although fusarium head blight resistance in CDC Imagine is less than that of AC Barrie (Anonymous 2005 in Anonymous 1995-2005). 


\section{Economic Impact}

Net economic returns have been reported to be higher for HR than non-HR canola production. In producer surveys conducted in 2000 (Koch Paul Associates 2000; Serecon Consulting Inc. and Koch Paul Associates 2001), net returns were 13 to 30\% greater for HR than non-HR canola. Greater yields, less dockage, improved seed quality, reduced herbicide costs, and reduced tillage costs contributed to the improved net returns. A recent study by O'Donovan et al. (2006) reported higher net returns for herbicide regimes in GLY-HR canola than those traditionally used in non-HR canola. The farm income benefit of transgenic-HR canola relative to non-HR canola from 1996 to 2004 has been estimated at US\$617 million (Brookes and Barfoot 2005).

Little information is available in Canada on net economic returns of HR soybean, corn, or wheat relative to their non-HR counterparts. In a survey of soybean producers in Ontario in 2002, the main reason for growing GLY-HR cultivars was the reduced cost of herbicide, labour, and fuel (Brethour et al. 2002). Those who did not grow GLY-HR soybean frequently cited potentially greater revenues from identity preservation (IP) contracts. The national farm income benefit of transgenic-HR soybean and corn relative to non-HR cultivars from 1996 to 2004 has been estimated at US\$55 and 16 million, respectively (Brookes and Barfoot 2005).

\section{Herbicide and Energy Use}

Opponents of transgenic-HR crops have argued that benefits accrue only to farmers or developers of the technology, not consumers or society at large. However, in 2000, transgenicHR canola had reduced herbicide use by 6000 tonnes (ca. 40\% reduction in total herbicide costs) (Serecon Management Consulting Inc and Koch Paul Associates 2001). Fuel consumption was reduced by 31 million litres that year because of fewer passes across fields due to less tillage, etc. In the early $2000 \mathrm{~s}$, HR canola was grown in a zero-tillage regime by $35 \%$ (IMI-HR) to $45 \%$ (GLU-HR) of producers (J. Y. Leeson and A. G. Thomas, unpubl. data). Reduced fuel usage in transgenic-HR vs. non-HR canola resulted in a reduction in carbon dioxide emissions of 94 million kg from 1996 to 2004 (Brookes and Barfoot 2005). In addition, a reduction in carbon dioxide emissions of 906 million $\mathrm{kg}$ during this period was attributed to soil carbon sequestration as a result of less tillage in transgenic-HR than non-HR canola. From 1995 to 2000, the amount of herbicide active ingredient applied per hectare of canola declined by $43 \%$ and the environmental impact (EI) per hectare, calculated using the environmental impact quotient for individual herbicides and the amounts of active ingredients applied, declined by $37 \%$ (Brimner et al. 2005, Figure 3). The amount of herbicide active ingredient and EI of herbicide use per hectare in non-HR canola were consistently greater than that of HR canola from 1996 to 2000. This decline in herbicide use and EI since introduction of HR cultivars was due to the use of herbicides at lower application rates, a reduced number of applications, and a decreased need for herbicide combinations. From 1996 to 2004, Brookes and Barfoot (2005) estimated that transgenic-HR canola resulted in a $20 \%$ reduction in EI of herbicide use per hectare relative to non-HR canola. Leeson et al. (2005a) found a similar reduction in EI of herbicide use per hectare from the 1990s to 2005 in HR compared with non-HR canola productions systems in the prairies. O'Donovan et al. (2006) confirmed that GLY-HR canola generally requires less herbicide active ingredient being applied to the environment compared with herbicide regimes traditionally used in non-HR canola. 
Similar to HR canola, GLY-HR soybean has resulted in fewer (average of 1.7) passes across fields and facilitated the adoption of conservation tillage (Brethour et al. 2002). Producers who grew GLY-HR soybean often cited reduced herbicide and fuel usage. From 1996 to 2004, transgenic-HR soybean and corn in Canada resulted in an 8 and $4 \%$ reduction, respectively, in EI of herbicide use per hectare relative to that of non-HR cultivars (Brookes and Barfoot 2005).

\section{Herbicide-Resistant Crops and Weed Shifts}

HR canola combined with reduced tillage or direct seeding have been significant factors influencing weed communities. HR canola may decrease the use of nonselective herbicides applied PP, preharvest, and postharvest by allowing early in-crop weed control and improved control of perennial weeds. Over time, weed shifts may occur where some weed species are poorly controlled within an HR system. In a western Canada study that included various GLYHR and non-GLY-HR wheat and canola rotations, some weeds with inherently high GLY tolerance tended to associate with the continuous in-crop GLY regime (Harker et al. 2005). However, a greater number of more common and dominant weed species were associated with the regime lacking in-crop GLY. Prairie field surveys of residual (post-herbicide treatment) weed species abundance in the 1990s and 2000s showed a decline in annual broadleaf, facultative winter annuals and perennials, but an increase in grassy species associated with HR canola production systems (Thomas et al. 2004). For example, species such as stinkweed declined in relative abundance, while that of green foxtail [Setaria viridis (L.) Beauv.], wild oat (Avena fatua L.), and volunteer crops increased in HR vs. non-HR canola systems. It is apparent that specific herbicide regimes favour specific weed communities, and that diverse herbicide regimes reduce the likelihood of weed population shifts.

\section{Herbicide-Resistant Crops and Weed Resistance}

The judicious use of HR crops can slow the selection of HR weeds by increasing herbicide rotation options, such as the substitution of high-risk (i.e., probable resistance evolution after 10 or fewer applications) herbicides with lower-risk products. Non-selective herbicides used in HR crops in North America have been a powerful tool to proactively and reactively manage HR weeds, such as those resistant to high-risk herbicides including ACCase inhibitors (group 1) and ALS inhibitors (group 2) (Beckie 2006). As a result, the potential economic impact of these HR weeds has been diminished. However, frequent use of HR crops in cropping systems, resulting in recurrent application of herbicides of the same mode of action, may select for new HR weed biotypes or augment the selection that has occurred previously. Potential impact of HR crops on selection for weed resistance is largely dependent on the size and intensity of the cropped area in an agricultural region and herbicide mode of action.

Occurrence of GLU (group 10)-HR weeds has not been reported in Canada or elsewhere. About one-third of GLU-HR canola producers tank-mix clethodim or another ACCase inhibitor with GLU to enhance grass weed control; GLU is rarely applied twice in-crop (J. Y. Leeson and A. G. Thomas, unpubl. data). Depending upon GLU efficacy, the tank-mix partner may contribute to ACCase inhibitor selection pressure in wild oat and other grass weeds and thus reduce the utility of GLU in combating ACCase inhibitor resistance. 
In the prairies, ALS inhibitor herbicides are often applied to one-third or more of cropped land each year (Leeson et al. 2005b). Usage is greatest in the Parkland region (Figure 4). Moreover, use of residual ALS inhibitor products in consecutive years is a common practice. In Manitoba in 2002, 41\% of residual ALS inhibitor herbicides were applied back-to-back (Figure 4). The largest class of HR weeds in Canada and world-wide are those resistant to ALS inhibitors. The use of ALS inhibitor herbicides in IMI-HR crops will continue the selection for ALS inhibitorHR broadleaf and grass weeds. Although 2,4-D is mixed with imazamox for use in IMI-HR wheat, broadleaf weeds poorly controlled by 2,4-D will be exposed to the same ALS inhibitor selection pressure as that from imazamox alone. With the commercial release of IMI-HR lentil (Lens culinaris L.) in 2006, ALS inhibitors could be used in every major crop in western Canada, including both conventional and IMI-HR crops. Unless IMI-HR crops and ALS inhibitor herbicides are used wisely, their commercial success will be limited.

Since the introduction of GLY-HR crops in the mid-1990s, several weed species resistant to the herbicide have been reported (Heap 2005). The majority of GLY-HR biotypes were not a consequence of GLY selection pressure in HR field crop production systems, but in orchards and vineyards, roadsides, or non-HR crops (e.g., PP, pre- or post-harvest). Since 2000, however, evolution of three GLY-HR biotypes, described below, have been linked to GLY-HR cropping systems in the United States. Although the majority of GLY-HR canola producers in western Canada apply GLY twice in-crop, less than $15 \%$ of the total area treated annually with herbicides receives an in-crop GLY application (Thomas et al. 2002; Leeson et al. 2004, 2005c). Selection intensity is generally greatest at this herbicide application timing (Beckie 2006). In comparison, frequency of total GLY usage ranges from 34\% (Alberta and Manitoba) to 62\% (Saskatchewan) of land cropped to cereals, oilseeds, or pulses (J. Y. Leeson and A. G. Thomas, unpubl. data). Relatively high GLY usage in Saskatchewan is linked to the adoption of zero tillage; 39, 27, and $13 \%$ of cropland in Saskatchewan, Alberta, and Manitoba, respectively, is planted using zerotillage practices (Statistics Canada 2002). Therefore, the contribution of GLY-HR canola to overall GLY selection pressure in prairie cropping systems is relatively low.

In contrast, the risk of evolved GLY resistance in weeds as a consequence of HR soybean cultivation is markedly greater in eastern Canada. Herbicide use in soybean in southwestern Ontario has changed dramatically over the past decade. In 1997, more than $75 \%$ of the crop in Ontario was treated with at least one ALS inhibitor (Beckie et al. 2001a). In some regions of Ontario, farmers had switched from a traditional corn, soybean, and winter wheat rotation to near monoculture of soybean, creating a high selection pressure for ALS inhibitor-HR broadleaf weeds such as Amaranthus spp. (Beckie et al. 2001a). With the rapid adoption of GLY-HR soybean since the late 1990s, use of ALS inhibitor herbicides in soybean has markedly declined. The reduction in ALS inhibitor selection pressure, however, has been countered by a corresponding increase in GLY selection pressure. In various regions of the United States, sequential in-season applications combined with near GLY-HR soybean monoculture (or GLYHR cotton) have contributed to the evolution of GLY-HR Canada fleabane [Conyza canadensis (L.) Cronq.] across a large area in more than 10 states, GLY-HR common ragweed (Ambrosia artemisiifolia L.) in Missouri, and GLY-HR Palmer amaranth (Amaranthus palmeri S. Wats.) in Georgia (Heap 2005). Such practices create an intense selection pressure for weed resistance and jeopardize the future utility of this important herbicide. Ontario soybean producers are currently 
re-creating this scenario. Given the importance of GLY in reduced-tillage cropping, monoculture GLY-HR soybean and multiple in-crop GLY applications in soybean or other crops should be dissuaded. The inexpensive cost of GLY relative to total variable costs and its lack of soil residual activity are disincentives for a reduction in herbicide-use intensity. Nevertheless, implementation of IWM practices in GLY-HR soybean, such as an intermediate $(38 \mathrm{~cm})$ rather than a wide $(76 \mathrm{~cm})$ row spacing (Figure 5), as well as in other GLY-HR crops can markedly reduce the real or perceived need for sequential in-crop GLY applications.

\section{Gene Flow and its Consequences}

Gene flow has occurred since crops were first grown, but the HR traits in crops provide simple, convenient, and precise markers to measure frequency and distance of gene flow. While the agronomic, economic, and environmental consequences of gene flow are difficult to quantify, the movement or 'escape' of HR genes has been widely and sensationally reported. These reports impact the general public's perception of biotechnology safety.

Gene flow can occur via pollen if the crop species is a partial or obligate outcrosser. If HR cultivars are grown in close proximity to non-HR cultivars, HR genes may be transferred to nonHR plants and hybrid seed formed. HR crops with outcrossing potential include canola, corn, and to a lesser extent, wheat (Table 2). Genes may also move via seed, which is both the delivery system for technology and the product harvested. Seed can remain viable in the seed bank for many years, germinate, and grow in subsequent crops as a 'volunteer' and become mixed (termed admixture) with other cultivars or crops in planting or harvesting equipment, and bulk storage facilities (Hall et al. 2003). Therefore, gene flow via seed has the potential to influence agriculture temporally and on a much larger scale than gene flow via pollen. The mechanism of gene movement is often difficult to determine because a combination of pollen and seed movement may have occurred.

\section{Intraspecific Gene Flow and Adventitious Presence}

In canola where outcrossing averages $30 \%$ and where more than one HR trait have been developed, pollen-mediated gene flow can result in multiple-HR (i.e., gene-stacked) volunteers. Multiple-HR canola volunteers were first documented in the late 1990s (Hall et al. 2000). In 1997 in northern Alberta, a field of GLY-HR canola was grown adjacent to a field of GLU-HR and IMI-HR canola. Volunteers were selected with GLY in 1998. These volunteers flowered and produced seeds that contained individuals resistant to GLY and GLU; GLY and IMI; and GLY, IMI, and GLU. Two triple-HR individuals were detected, with one plant located $550 \mathrm{~m}$ from the pollen source.

A subsequent study was conducted at 11 commercial field sites in Saskatchewan in 1999, where GLY-HR canola was grown adjacent to GLU-HR canola (Beckie et al. 2003). Gene flow ranged from $1.4 \%$ outcrossing at the border common to the paired fields to $0.04 \%$ at $400 \mathrm{~m}$ (Figure 6). Thus, outcrossing distance was greater than the 100-m isolation distance currently regulated for seed producers (CSGA 2005), and greater than the 175-m buffer zone recommended to commercial canola producers. Thus, harvested seeds of canola grown in proximity to a different HR canola system may contain individuals with multiple herbicide resistance. 
The majority $(80 \%)$ of producers purchase certified canola seed from seed producers who strive to preserve varietal integrity (Koch Paul Associates 2000; Serecon Management Consulting Inc. and Koch Paul Associates 2001). Data from two Canadian studies have documented AP levels in certified seed. Downey and Beckie (2002) found that 34 of 70 certified canola seedlots tested from 14 non-HR, open-pollinated cultivars produced in 2000 contained the gene conferring GLY resistance, and 41 seedlots (59\%) contained the GLY- or GLU-HR gene. Four of 14 cultivars tested exceeded an HR frequency of $0.25 \%$. Only two of the 14 cultivars were free of both genes. In a subsequent examination of 27 seedlots (excluding GLY-HR) by Friesen et al. (2003), 78\% were found to have the GLY-HR gene, 96\% had either the GLY or GLU-HR gene, and 52\% exceeded a frequency of $0.25 \%$. Data from both studies suggested that most of the AP had occurred in breeding nurseries during the development of the cultivars and not during the pedigreed seed multiplication process (e.g., admixture during the planting, harvesting, or cleaning operations). In Canada, a maximum of $0.25 \% \mathrm{AP}$ is permitted in certified canola seed (CSGA 2005). Before the introduction of HR traits, there were no definitive genetic markers to precisely quantify levels of genetic purity in canola cultivar seedlots. Breeders and seed companies are now monitoring seedlots for AP using commercially available test strips or seed assays. Although the purity threshold is seemingly high (99.75\%), the small size of canola seed and the commonly used seeding rates can result in a significant number of AP seeds planted per hectare. For example, assuming that $0.25 \%$ of the seeds in a seedlot are double-HR, this would result in a potential seed bank of about 5 double-HR plants $\mathrm{m}^{-2}$ or 50,000 plants ha $^{-1}$.

Together, AP in pedigreed canola seedlots planted and pollen-mediated gene flow can result in large, unexpected populations of single- or multiple-HR canola, and canola volunteers in subsequent years. Beckie et al. (2003) found that in the year following canola (2000) when volunteers were mapped and characterized, gene flow as a result of pollen flow in 1999 was detected to $800 \mathrm{~m}$, the limit of the study areas (Figure 7). Large variation in gene flow levels and patterns among sites was evident. The AP of double (GLY+GLU)-HR seed in GLY-HR seedlots planted at some of the sites in 1999 contributed to the occurrence of double-HR canola volunteers in 2000. The results of the study suggest that HR gene stacking in canola volunteers in western Canada is common, and reflects pollen flow between different HR canola systems, AP in seedlots, and/or agronomic practices employed by Canadian farmers.

Whereas $B$. napus canola is a moderately outcrossing species, corn is highly outcrossing (Table 2). Pollen-mediated transgene (Bt) movement to non-transgenic corn was investigated in field experiments at Ottawa from 2000 to 2002 (Ma et al. 2004). Maximum outcrossing of $82 \%$ occurred in plants immediately adjacent to Bt corn, and declined exponentially to less than $1 \%$ at $28 \mathrm{~m}$ from the moderately-sized ( 27 by $27 \mathrm{~m}$ ) pollen source. The authors concluded that the current isolation distance between genotypes of $200 \mathrm{~m}$, which is generally recommended for seed producers, is appropriate for $\mathrm{Bt}$ or $\mathrm{HR}$ corn.

The frequency and distance of pollen-mediated gene flow in non-HR wheat have been documented from a small ( 5 by $5 \mathrm{~m}$ ) and a medium-sized ( 50 by $50 \mathrm{~m}$ ) pollen source (Hucl and Matus-Cádiz 2001; Matus-Cádiz et al. 2004). Gene flow varied with cultivar, but remained below $0.5 \%$ and decreased over distance; however, gene flow via pollen $(0.005 \%)$ was measured at $300 \mathrm{~m}$ from the pollen source. Current studies are investigating pollen-mediated gene flow 
from IMI-HR wheat to non-HR wheat in commercial fields (H. Beckie et al. unpubl. data). Because IMI-HR wheat is non-transgenic, AP in grain shipments is not a concern to buyers.

To date, there have been no changes in commodity market acceptance of the four crops due to the presence of HR genes because non-HR and HR crops are co-mingled for domestic sale or export. The consequences of gene flow in canola or AP in seedlots in Canada have largely been restricted to the organic canola and honey market. Consequences of single- or stacked-HR volunteers for both adopters and non-adopters of HR crops are described in the next section.

\section{Managing Single- or Multiple-Herbicide-Resistant Crop Volunteers}

Volunteer canola (mainly HR) was ranked 12th in relative abundance in prairie weed surveys conducted from 2001 to 2003; however, relative abundance ranking had declined from 10th position as determined from surveys conducted in the mid-1990s when canola was mainly nonHR (Leeson et al. 2005d). In contrast, volunteer non-HR wheat increased in rank from 18th to 8th place from the 1990s to 2000s, suggesting that the HR trait is not a major factor influencing volunteer canola abundance.

Canola can produce large volunteer populations because of the large amount of seed lost before and at harvest. In a study in Saskatchewan in 1999 and 2000, average canola seed loss during harvest operations was $5.9 \%$ of crop yield $\left(3,000\right.$ viable seeds $\left.\mathrm{m}^{-2}\right)$ as determined from measurements in 35 producers' fields (Gulden et al. 2003a); yield loss among producers ranged from 3.3 to $9.9 \%$ or 9 to 56 times the recommended seeding rate of canola. Additionally, canola can have a persistent seed bank because of the potential for induction of secondary dormancy (Gulden et al. 2003b, 2004). Volunteers can occur for at least 4 to $5 \mathrm{yr}$ after production (Légère et al. 2001; Simard et al. 2002), although most occur in the first year after canola (Harker et al. 2006), particularly when there is no seed bank replenishment.

Herbicides are the dominant weed control tool for managing single- or multiple-HR canola volunteers. Those volunteers possessing GLY resistance are most likely to be noticed because GLY is used for PP burndown and chem-fallow, whereas GLU and ALS inhibitors are not. In western Canada, GLU is used primarily in GLU-HR canola and marginally as a desiccant in seed alfalfa (Medicago sativa L.), lentil, and potato (Solanum tuberosum L.). Volunteers possessing IMI resistance may remain in cereals or field pea (Pisum sativum L.) where only ALS inhibitors are applied. In the year following HR canola, volunteers are best controlled in-crop (Harker et al. 2006) and at the four-leaf stage or earlier (Beckie et al. 2004). Cool temperatures in spring may result in poor control of volunteers because of reduced herbicide uptake, but cold hardening does not alter their sensitivity to herbicides such as 2,4-D (Simard and Légère 2003).

All volunteers, whether non-HR, single-HR, or multiple-HR, can be controlled equally well by herbicides with alternative modes of action, such as metribuzin, 2,4-D, or MCPA (Beckie et al. 2004). There are over 30 registered herbicide treatments for control of single- or multiple-HR canola volunteers in cereals (Anonymous 2005), the most frequent crop type to follow canola in a typical 4-yr rotation (Serecon Management Consulting Inc. and Koch Paul Associates 2001). In some instances, herbicide mixtures are recommended. For example, GLY can be mixed with 2,4-D to control volunteers before planting a cereal crop that follows GLY-HR canola in rotation (Harker et al. 2006). This extra herbicide use and cost in low disturbance, direct-seeding systems 
has been highlighted as a significant problem of GLY-HR canola (Friesen et al. 2003; Van Acker et al. 2003). However, an analysis of non-HR and HR volunteer canola management practices, based on a survey of 335 canola producers in 2004 and weed surveys conducted in western Canada from 2001 to 2003 (Serecon Management Consulting Inc. 2005), indicated that herbicide use to control volunteer canola was similar across canola and tillage systems. Three-quarters of farmers who grew transgenic-HR canola in 2000 indicated that management of canola volunteers was equal or no more of a problem with transgenic-HR cultivars than with non-HR cultivars (Serecon Management Consulting Inc. and Koch Paul Associates 2001). The later survey (Serecon Management Consulting Inc. 2005) noted the same result and found that (1) few farmers target herbicide treatments or tillage operations specifically for volunteer canola; (2) a majority of farmers were not targeting volunteer canola more than they had in the past, nor had they changed their weed management practices to control volunteer canola; (3) the incidence of tillage to control volunteers was similar across canola systems; (4) there were no significant differences among canola systems in the costs (herbicides or tillage) of volunteer canola control, as estimated by the respondents; (5) herbicide options and timing of application were generally similar across canola systems, with ALS inhibitors (except for IMI-HR canola) and synthetic auxin herbicides used most often for in-crop volunteer canola control; (6) the percentage of fields with residual (post-herbicide treatment) volunteer canola was similar across all systems, and abundance rarely exceeded an economic threshold of 10 plants $\mathrm{m}^{-2}$; (7) herbicide use and weed abundance were similar in the crop following non-HR and HR canola; in addition, volunteer canola was often not targeted for control 2 yr after the canola crop; and (8) slightly more GLYHR than non-HR producers controlled volunteer canola with a herbicide application, although the percentage of area treated $(<20 \%)$ was similar across systems. The survey also found that producers often use multiple canola systems and rotate systems from year to year.

Cultural or mechanical practices that are recommended to farmers to manage multiple-HR canola volunteers (Thomas 2001) include: (1) leaving seeds on or near the soil surface as long as possible after harvest because a high percentage will germinate in the fall and be killed by frost (Légère et al. 2001), whereas seeds incorporated into the soil may develop secondary dormancy that will increase persistence (Gulden et al. 2003b); (2) using tillage immediately before planting; (3) silaging and green manuring crops to prevent seed set in volunteers; (4) isolating fields of canola with different HR traits to reduce outcrossing; (5) following canola with a cereal crop and not some annual legumes such as lentil or chickpea (Cicer arietinum L.) or oilseed crops such as sunflower (Helianthus annuus L.), because of few or no in-crop herbicide options; rotating canola in a 4-yr diverse cropping sequence will deplete volunteers from the seed bank over time and facilitate use of herbicides with different modes of action; (6) scouting fields for volunteers not controlled by weed management treatments and preventing seed set; (7) using pedigreed seed to reduce the probability of AP presence; and (8) reducing seed loss during harvest by swathing at the correct crop development stage and properly adjusting combine settings.

In sharp contrast to canola, soybean has no weedy tendencies (Table 2). Crop seed rarely exhibits dormancy, and the species usually does not occur as a volunteer in the year following crop cultivation (Frick and Thomas 1992; CFIA 1996). If volunteers do occur, they are poor competitors and are easily controlled chemically or mechanically. 
One of the concerns with the introduction of GLY-HR corn in Ontario in the late 1990s was the possibility of volunteer GLY-HR corn in GLY-HR soybean. Recently-harvested corn kernels exhibit little dormancy, but the species can occur as volunteers in the year following cultivation of the crop (Beckett and Stoller 1988; CFIA 1994). There is no evidence of persistence of this species in the seed bank beyond the first year after the crop is grown. In weed surveys conducted in 1988 and 1989 in Ontario, volunteer corn ranked 28th among 37 species with a mean plant density of $0.1 \mathrm{~m}^{-2}$; it occurred in only $6 \%$ of fields (Frick and Thomas 1992). Volunteers were present in soybean fields but not in winter wheat fields, and tended to be associated with zerotillage systems. Volunteer GLY-HR corn in GLY-HR soybean can result in yield losses of up to 47\% (Soltani et al. 2006). HR corn volunteers can be controlled in non-GLY-HR soybean by several ACCase inhibitors, including quizalofop, fluazifop, fenoxaprop, clethodim, and sethoxydim. Whereas non-HR corn volunteers can be controlled by GLY in GLY-HR soybean, quizalofop is currently the only registered GLY tank-mix partner for the control of volunteer GLY-HR corn in GLY-HR soybean; this tank-mixture in GLY-HR soybean controlled 93\% of GLY-HR corn volunteers (Soltani et al. 2006). Thus, rotating between non-HR and HR corn and soybean can reduce weed control costs (Cowbrough 2004).

IMI-HR wheat volunteers can be controlled by GLY applied PP or in GLY-HR canola. Alternatively, they can be controlled by ACCase inhibitors in canola or other broadleaf crops or by GLU in canola (Anonymous 2005). All wheat cultivars are poorly controlled in barley. Thus, IMI-HR wheat is no more difficult to control than non-HR cultivars.

\section{Interspecific Pollen-Mediated Gene Flow}

Current studies are determining the extent of pollen flow from GLY-HR canola to other Brassica crops, including oriental mustard (Brassica juncea L.) and Polish canola (B. rapa L.). Gene flow to both crops has been documented up to 200 m (Warwick 2005; G. Séguin-Swartz et al., unpubl. data). The consequence of gene flow to Polish canola, which only occupies about $2 \%$ of the total canola area (M. Gerhardt, pers. comm.), is generally negligible. However, at present there are no established thresholds for transgene AP in $B$. juncea mustard. Current regulations for pedigreed mustard seed producers stipulate a $100-\mathrm{m}$ buffer zone separating $B$. napus canola and $B$. juncea mustard (CSGA 2005).

In addition to evolved weed resistance via herbicide selection pressure, resistance may also occur through gene flow. Interspecific hybridization with weedy relatives and subsequent genome introgression is a key biosafety issue of HR crops. Evolved weed resistance through selection pressure in HR crops generally poses a greater risk than resistance in related weed species through gene flow (Warwick et al. 1999, 2004; Beckie et al. 2001b). A notable exception is gene flow from HR canola to bird's rape (Brassica rapa L.) in eastern Canada (Warwick et al. 2003).

The frequency of gene flow from canola to four wild relatives, bird's rape, wild mustard, dog mustard [Erucastrum gallicum (Willd.) O.E. Schulz], and wild radish (Raphanus raphanistrum L.) was assessed in greenhouse or field experiments, and actual rates were measured in commercial fields in Canada (Warwick et al. 2003). Bird's rape has a limited distribution as an agricultural and/or ruderal weed in canola-growing areas in Québec (Warwick et al. 2003; Simard et al. 2005b). In Québec in 2005, canola (GLY- and GLU-HR) was cultivated on 14,000 ha (Statistics Canada 2005). Hybridization between bird's rape and canola occurred in two field 
experiments (7\% frequency), and in indigenous populations in commercial fields in Québec $(14 \%)$. The higher frequency in commercial fields was attributed to greater distance separating bird's rape plants. Hybrids were morphologically similar to bird's rape, had reduced pollen viability (about 55\%), and segregated for both self-incompatible and self-compatible individuals. Such hybridization was not unexpected as $B$. rapa is a progenitor of $B$. napus. In contrast, gene flow between canola and wild radish was rare. A single hybrid was detected in 32,821 seedlings from a field experiment. The hybrid was morphologically similar to wild radish except for the presence of valves, and had less than $1 \%$ pollen viability. No hybrids were detected in commercial fields in Québec or Alberta (22,114 seedlings). Similarly, no wild or dog mustard $\mathrm{x}$ canola hybrids were detected (42,828 and 21,841 seedlings, respectively) from commercial fields in Saskatchewan. These findings suggest that the probability of gene flow from transgenic-HR canola to wild radish, wild mustard, or dog mustard is very low $\left(<2-5 \times 10^{-5}\right)$. However, transgenes can disperse in the environment via bird's rape in eastern Canada and possibly via commercial Polish canola volunteers in western Canada. Introgression of transgenes in $B$. rapa populations occurs with apparently little or no fitness costs (Snow et al. 1999). Enrichment of these transgenic plants in the population, however, should only occur when and where herbicide selection pressure is applied.

In contrast to canola, soybean is highly selfing and no wild relatives occur in Canada (CFIA 1996). Therefore, interspecific hybridization between soybean and wild relatives is not a biosafety issue. In the absence of sexually-compatible relatives of corn in Canada, there is also no potential for interspecific gene flow to occur for this crop (CFIA 1994). Weedy relatives of wheat, particularly jointed goatgrass (Aegilops cylindrica Host.), are not known to occur in Canada, therefore interspecific gene flow is not a concern currently. However, intensive field surveys should routinely be conducted in winter cereals in the southern prairies to monitor for the occurrence of the weed, which is found just across the international border.

\section{Herbicide-Resistant Crop Volunteers in Disturbed or Natural Ecosystems}

HR volunteers of these four crops are not considered noxious weeds, nor invasive in natural (unmanaged) ecosystems (Table 2). Where herbicides are used in non-crop disturbed areas, the potential invasiveness of HR crops, such as canola, may be greater. For example, the use of GLY or ALS inhibitors at oilwell sites or along railways or roadsides adjacent to cropland might result in a lack of control of HR crop volunteers. However, because vegetation in natural areas is rarely exposed to herbicides, it is unlikely that HR traits will increase invasiveness of crops into such areas (Beckie et al. 2001a). Nevertheless, the consequence of transgene spread to nonagricultural habitats is largely undocumented (Légère 2005; Warwick 2005).

Previous studies have shown little difference in fitness among non-HR, single-HR, or multipleHR canola in the absence of herbicide selection, suggesting HR canola volunteers do not have any greater capacity than non-HR plants to invade disturbed or natural areas (e.g., Simard et al. 2005a). Those findings and the results of Beckie et al. (2004) indicate that single- or multipleHR canola volunteers are not more weedier than non-HR plants in either disturbed sites where they can be controlled by herbicides of alternative modes of action or in natural ecosystems where enhanced fitness would only be evident if herbicide selection pressure were to be applied. 


\section{Herbicide-Resistant Crops and Weed Diversity}

An important question surrounding HR crops, particularly in Europe, is the impact of such crops on weed diversity. This question was addressed through field surveys conducted in the 1990s (pre-HR canola) and 2000s (post-HR canola) of residual weed species diversity (Thomas et al. 2004). Weed species diversity in non-HR wheat (not grown on canola stubble) in these two periods was used as a basis for comparison. Weed diversity was measured by species richness (number of species per field), evenness (Shannon's Evenness index), and dominance (BergerParker index) (A. G. Thomas et al., unpubl. data). Differences in weed communities before and after the adoption of HR canola were found to be similar to those observed in wheat, suggesting that HR canola has not reduced weed diversity. Although weed species richness (Figure 8) and mean densities (data not shown) were less in HR than non-HR canola, the weed diversity decline in wheat in the 2000s vs. 1990s was proportionally greater, suggesting that environment (belownormal precipitation in 2000s) and management practices (e.g., further adoption of conservation tillage or improved herbicide application timing) were mainly responsible. Little change in effectiveness of herbicides used in wheat between the two periods compared with those used in HR vs. non-HR canola supported this conclusion.

In western Canada, very few agricultural weed species are native and none are rare or threatened (Thomas et al. 2004), thus the impact of HR crops on weed diversity is not as important an issue as in the centers of origin of these species. The abundance of native weed species relative to that of all species has not changed between HR and non-HR canola. Nevertheless, weed diversity in HR canola should continue to be monitored. Although less than 5\% of the prairies (total area of 113 million ha) is cropped annually to HR canola, its impact on prairie ecosystem biodiversity as a whole has not been examined. In eastern Canada, research is required on the impact of HR corn and soybean on weed species diversity.

Anonymous. 1995-2005. Varieties of grain crops. Saskatchewan Agriculture, Food and Rural Revitalization, Regina, SK.

Anonymous. 2005. 2005 Guide to crop protection: weeds, plant diseases, insects. Saskatchewan Agriculture, Food and Rural Revitalization, Regina, SK; and Manitoba Agriculture, Food and Rural Initiatives, Winnipeg, MB. 354 pp.

Beckett, T. H. and Stoller, E. W. 1988. Volunteer corn (Zea mays) interference in soybeans (Glycine max). Weed Sci. 36: 159-166.

Beckie, H. J. 2006. Herbicide-resistant weeds: management tactics and practices. Weed Technol. 20: in press.

Beckie, H. J., Hall, L. M. and Tardif, F. J. 2001a. Herbicide resistance in Canada - where are we today? Pages 1-36 in R. E. Blackshaw and L. M. Hall, eds. Integrated weed management: explore the potential. Expert Committee on Weeds. Sainte-Anne-de-Bellevue, QC.

Beckie, H. J., Hall, L. M. and Warwick, S. I. 2001b. Impact of herbicide-resistant crops as weeds in Canada. Pages 135-142 in Proc. Brighton Crop Protection Conference - Weeds. British Crop Protection Council, Farnham, Surrey, UK.

Beckie, H. J., Séguin-Swartz, G., Nair, H., Warwick, S. I. and Johnson, E. 2004. Multiple herbicide-resistant canola can be controlled by alternative herbicides. Weed Sci. 52: 152-157. 
Beckie, H. J., Warwick, S. I., Nair, H. and Séguin-Swartz, G. 2003. Gene flow in commercial fields of herbicide-resistant canola (Brassica napus). Ecol. Appl. 13: 1276-1294.

Bohner, H. 2003. What about yield drag on Roundup Ready soybean? Ontario Agriculture, Food and Rural Affairs. [Online]. Available:

http://www.omafra.gov.on.ca/english/crops/field/news/croptalk/2003/ct 0303a9.htm [27 August 2005].

Brethour, C., Mussell, A., Mayer, H. and Martin, L. 2002. Agronomic, economic and environmental impacts of the commercial cultivation of glyphosate tolerant soybeans in Ontario. Report prepared for the Council for Biotechnology Information (Canada). George Morris Centre, Guelph, ON. 56 pp. [Online]. Available: http://www.georgemorris.org [14 July 2005].

Brimner, T. A., Gallivan, G. J. and Stephenson, G. R. 2005. Influence of herbicide-resistant canola on the environmental impact of weed management. Pest Manag. Sci. 61: 47-52.

Brookes, G. and Barfoot, P. 2005. GM crops: the global economic and environmental impact the first nine years 1996-2004. AgBioForum 8: 187-196.

[CFIA] Canadian Food Inspection Agency. 1994. Regulatory directive dir94-11: the biology of Zea mays L. (corn/maize). A companion document to the assessment criteria for determining environmental safety of plants with novel traits. (CFIA) Canadian Food Inspection Agency, Plant Products Directorate, Plant Biosafety Office: Ottawa, ON. [Online]. Available: http://www.inspection.gc.ca/english/plaveg/bio/dir/dir9411e.shtml [25 May 2005].

[CFIA] Canadian Food Inspection Agency. 1996. Regulatory directive T-1-10-96: the biology of Glycine $\max (\mathrm{L}$.) Merr. (soybean). A companion document to the assessment criteria for determining environmental safety of plants with novel traits. (CFIA) Canadian Food Inspection Agency, Plant Products Directorate, Plant Biosafety Office: Ottawa, ON. [Online]. Available: http://www.inspection.gc.ca/english/plaveg/bio/dir/t11096e.shtml [25 May 2005].

Chandler, K., Shrestha, A. and Swanton, C. J. 2001. Weed seed return as influenced by the critical weed-free period and row spacing of no-till glyphosate-resistant soybean. Can. J. Plant Sci. 81: 877-880.

Clayton, G. W., Harker, K. N., O’Donovan, J. T., Blackshaw, R. E., Dosdall, L. M., Stevenson, F. C. and Ferguson, T. 2004a. Fall and spring seeding date effects on herbicide-tolerant canola (Brassica napus L.) cultivars. Can. J. Plant Sci. 84: 419-430.

Clayton, G. W., Harker, K. N., O'Donovan, J. T., Blackshaw, R. E., Dosdall, L., Stevenson, F. C., Johnson, E. N. and Ferguson, T. 2004b. Polymer seed coating of early- and latefall-seeded herbicide-tolerant canola (Brassica napus L.) cultivars. Can. J. Plant Sci. 84: 971979.

Cowbrough, M. 2004. Controlling volunteer corn in soybean. Ontario Agriculture, Food and Rural Affairs. [Online]. Available: http://www.omafra.gov.on.ca/english/crops/field/news/croppest/2004/08cpo04a6.htm [27 August 2005].

[CSGA] Canadian Seed Growers' Association. 2005. Regulations and procedures for pedigreed seed crop production. Circular 6, Version 20050108. [Online]. Available: http://www.seedgrowers.ca [27 August 2005]. 
[CWB] Canadian Wheat Board. 2004. 2004 Canadian Wheat Board variety survey. [Online]. Available: www.cwb.ca/en/growing/variety_survey/pdf/2004_variety_survey.pdf [10 August 2005].

[CWB] Canadian Wheat Board. 2005. 2005 Canadian Wheat Board variety survey. [Online]. Available: www.cwb.ca/en/growing/variety_survey/pdf/2005_variety_survey.pdf [9 January 2006].

Daun, J. K. 2004. Quality of genetically modified (GM) and conventional varieties of canola (spring oilseed rape) grown in western Canada, 1996-2001. J. Agric. Sci. 142: 273-280.

Devine, M. D. and Buth, J. L. 2001. Advantages of genetically modified canola: A Canadian perspective. Pages 367-372 in Proc. Brighton Crop Protection Conference - Weeds. British Crop Protection Council, Farnham, Surrey, UK.

Downey, R. K. and Beckie, H. J. 2002. Isolation effectiveness in canola pedigree seed production. Report to Canadian Seed Growers' Association. Agriculture and Agri-Food Canada, Saskatoon, SK. 14 pp.

Frick, B. and Thomas, A. G. 1992. Weed surveys in different tillage systems in southwestern Ontario field crops. Can. J. Plant Sci. 72: 1337-1347.

Friesen, L. F., Nelson, A. G. and Van Acker, R. C. 2003. Evidence of contamination of pedigreed canola (Brassica napus) seedlots in western Canada with genetically engineered herbicide resistance traits. Agron. J. 95: 1342-1347.

Gulden, R. H., Shirtliffe, S. J. and Thomas, A. G. 2003a. Harvest losses of canola (Brassica napus) cause large seedbank inputs. Weed Sci. 51: 83-86.

Gulden, R. H., Shirtliffe, S. J. and Thomas, A. G. 2003b. Secondary seed dormancy prolongs persistence of volunteer canola (Brassica napus) in western Canada. Weed Sci. 51: 904-913.

Gulden, R. H., Thomas, A. G. and Shirtliffe, S. J. 2004. Relative contribution of genotype, seed size and environment to secondary seed dormancy potential in Canadian spring oilseed rape (Brassica napus). Weed Res. 44: 97-106.

Hall, L. M., Good, A., Beckie, H. J. and Warwick, S. I. 2003. Gene flow in herbicide-resistant canola (Brassica napus): the Canadian experience. Pages 57-66 in T. Lelley, E. Balázs and M. Tepfer, eds. Ecological impact of GMO dissemination in agro-ecosystems. Facultas Verlags-und Buchhandels AG, Austria.

Hall, L., Topinka, K., Huffman, J., Davis, L. and Good, A. 2000. Pollen flow between herbicide-resistant Brassica napus is the cause of multiple-resistant B. napus volunteers. Weed Sci. 48: 688-694.

Harker, K. N., Blackshaw, R. E., Kirkland, K. J., Derksen, D. A. and Wall, D. 2000. Herbicide-tolerant canola: weed control and yield comparisons in western Canada. Can. J. Plant Sci. 80: 647-654.

Harker, K. N., Clayton, G. W., Blackshaw, R. E., O’Donovan, J. T., Johnson, E. N., Gan, Y., Holm, F. A., Sapsford, K. L., Irvine, R. B. and Van Acker, R. C. 2006. Persistence of glyphosate-resistant canola in western Canadian cropping systems. Agron. J. 98: 107-119.

Harker, K. N., Clayton, G. W., Blackshaw, R. E., O'Donovan, J. T., Lupwayi, N. Z., Johnson, E. N., Gan, Y., Zentner, R. P., Lafond, G. P. and Irvine, R. B. 2005. Glyphosate-resistant spring wheat production system effects on weed communities. Weed Sci. 53: 451-464.

Harker, K. N., Clayton, G. W., O'Donovan, J. T., Blackshaw, R. E. and Stevenson, F. C. 2004. Herbicide timing and rate effects on weed management in three herbicide-resistant canola systems. Weed Technol. 18: 1006-1012. 
Heap, I. M. 2005. International survey of herbicide resistant weeds. [Online]. Available: http://www.weedscience.org [2 May 2005].

Hucl, P. and Matus-Cádiz, M. 2001. Isolation distances for minimizing out-crossing in spring wheat. Crop Sci. 41: 1348-1351.

James, C. 2003. Preview: global status of commercialized transgenic crops: 2003. ISAAA Briefs No. 30. ISAAA, Ithaca, NY. [Online]. Available: http://www.isaaa.org [6 June 2005].

James, C. 2004. Preview: global status of commercialized biotech/gm crops: 2004. ISAAA Briefs No. 32. ISAAA, Ithaca, NY. [Online]. Available: http://www.isaaa.org [6 June 2005].

James, C. 2005. Global status of commercialized biotech/gm crops: 2005. ISAAA Briefs No. 34. ISAAA, Ithaca, NY. [Online]. Available: http://www.isaaa.org [30 January 2006].

Koch Paul Associates. 2000. Final report on integrated pest management practices in canola. Prepared in cooperation with Serecon for the Canola Council of Canada. Calgary, AB. 124 pp.

Leeson, J. Y., Thomas, A. G., Beckie, H. J., Brenzil, C. A., Hall, L. M., Andrews, T., Brown, K. R. and Van Acker, R. C. 2005a. Herbicide-use trends in prairie canola production systems. Proc. 2005 National Meeting of the Canadian Weed Science Society, Niagara Falls, ON. (in preparation).

Leeson, J. Y., Thomas, A. G., Beckie, H. J., Hall, L. M., Brenzil, C., Van Acker, R. C., Brown, K. R. and Andrews. T. 2005b. Group 2 herbicide use in the prairie provinces. Proc. 2004 National Meeting of the Canadian Weed Science Society, Sainte-Anne-de-Bellevue, QC (in press).

Leeson, J. Y., Thomas, A. G., Beckie, H. J., Van Acker, R. C. and Andrews, T. 2004. Do Manitoba producers reduce in-crop herbicide rates? Page 89 in J. R. Calder, P. Burgess, K. Jensen, G. Sampson, and D. Cloutier, eds. Proc. 2003 National Meeting of the Canadian Weed Science Society. [Online]. Available: http://www.cwss-scm.ca [31 May 2005].

Leeson, J. Y., Thomas, A. G., Brenzil, C. A. and Beckie, H. J. 2005c. Do Saskatchewan producers reduce in-crop herbicide rates? Proc. 2004 National Meeting of the Canadian Weed Science Society, Sainte-Anne-de-Bellevue, QC (in press).

Leeson, J. Y., Thomas, A. G., Hall, L. M., Brenzil, C. A., Andrews, T., Brown, K. R. and Van Acker, R. C. 2005d. Prairie weed surveys of cereal, oilseed and pulse crops from the 1970s to the 2000s. Weed Survey Series Publ. 05-1. Agriculture and Agri-Food Canada, Saskatoon Research Centre, Saskatoon, SK. 395 pp.

Légère, A. 2005. Risks and consequences of gene flow from herbicide-resistant crops: canola (Brassica napus L.) as a case study. Pest Manag. Sci. 61: 292-300.

Légère, A., Simard, M.-J., Thomas, A. G., Pageau, D., Lajeunesse, J., Warwick, S. I. and Derksen, D. A. 2001. Presence and persistence of volunteer canola in Canadian cropping systems. Pages 143-148 in Brighton Crop Prot. Conf. - Weeds. British Crop Protection Council, Farnham, Surrey, UK.

Ma, B. L., Subedi, K. D. and Reid, L. M. 2004. Extent of cross-fertilization in maize by pollen from neighboring transgenic hybrids. Crop Sci. 44: 1273-1282.

Matus-Cádiz, M. A., Hucl, P., Horak, M. J. and Blomquist, L. K. 2004. Gene flow in wheat at the field scale. Crop Sci. 44: 718-727.

O'Donovan, J. T., Harker, K. N., Clayton, G. W. and Blackshaw, R. E. 2006. Comparison of a glyphosate-resistant canola (Brassica napus L.) system with traditional herbicide regimes. Weed Technol. (in press). 
Ontario Corn Committee. 2005. 2004 hybrid corn performance trials. [Online]. Available: http://www.ontariocorn.org/2004performancetrials.htm [9 September 2005].

Ontario Soybean Growers. 2005. Glyphosate-tolerant soybean acreage [Online]. Available: http://www.soybean.on.ca [25 July 2005].

[OOPSCC] Ontario Oil and Protein Seed Crop Committee. 2005. 2005 report: Ontario soybean variety trials for 2002-2004. [Online]. Available:

http://www.oopscc.org/2005_OSV_Report.pdf [27 August 2005].

Serecon Management Consulting Inc. 2005. Herbicide tolerant volunteer canola management in subsequent crops. Report prepared for the Canola Council of Canada. Calgary, AB. 49 pp. [Online]. Available: http://www.canola-council.org/PDF/ht_canola_final.pdf [20 July 2005].

Serecon Management Consulting Inc. and Koch Paul Associates. 2001. An agronomic and economic assessment of transgenic canola. Report prepared for the Canola Council of Canada. Calgary, AB. 57 pp. [Online]. Available: http://www.canolacouncil.org/production/gmo toc.html [15 July 2005].

Simard, M.-J. and Légère, A. 2003. Control of volunteer canola with auxinic herbicides. Does cold hardening or plant size matter? Page 166 in H. Beckie, N. Harker, E. Johnson, M. Lawton, A. Mulenga, T. Wolf and D. Cloutier, eds. Proc. 2002 National Meeting of the Canadian Weed Science Society, Saskatoon, SK. [Online]. Available: http://www.cwssscm.ca [20 July 2005].

Simard, M.-J., Légère, A., Pageau, D., Lajeunesse, J. and Warwick, S. 2002. The frequency and persistence of volunteer canola (Brassica napus) in Québec cropping systems. Weed Technol. 16: 433-439.

Simard, M.-J., Légère, A., Séguin-Swartz, G., Nair, H. and Warwick, S. 2005a. Fitness of double vs. single herbicide-resistant canola. Weed Sci. 53: 489-498.

Simard, M.-J., Légère, A. and Warwick, S. 2005b. Distribution and abundance of bird rape (Brassica rapa) in transgenic canola (B. napus) field margins in Québec. National Meeting of the Canadian Weed Science Society, Niagara Falls, ON. (in press).

Snow, A. A., Andersen, B. and Jørgensen, R. B. 1999. Costs of transgenic herbicide resistance introgressed from Brassica napus into weedy Brassica rapa. Mol. Ecol. 8: 605-615.

Soltani, N., Shropshire, C. and Sikkema, P. H. 2006. Control of volunteer glyphosate-tolerant maize (Zea mays) in glyphosate-tolerant soybean (Glycine max). Crop Prot. 25: 178-181.

Statistics Canada. 2002. Census of agriculture 2001. Table 7 - tillage practices used to prepare land for seeding, by province, census agricultural region and census division [CD-ROM]. Stat. Reference Cent., Stat. Canada., Ottawa, ON.

Statistics Canada. 2005. November estimate of production of principal field crops, Canada, 2005. Field Crop Reporting Series Vol. 84, No. 8. Catalogue No. 22-002-XPB. 22 pp.

Stringam, G. R., Ripley, V. L., Love, H. K. and Mitchell, A. 2003. Transgenic herbicide tolerant canola - the Canadian experience. Crop Sci. 43: 1590-1593.

Thomas, A. G., Hall, L. M., Leeson, J. Y., Beckie, H. J., Van Acker, R. C. and Brenzil, C. A. 2004. Has the use of herbicide-tolerant canola crops altered weed diversity in western Canada? Page 109 in Proc. Fourth International Weed Science Congress, Durban, S.A. Inter. Weed Sci. Soc., Davis, CA.

Thomas, A. G., Leeson, J. Y., Hall, L. M. and Beckie, H. J. 2002. Do Alberta producers reduce in-crop herbicide rates? Page 174 in H. Beckie, N. Harker, E. Johnson, M. Lawton, A. Mulenga, T. Wolf and D. Cloutier, eds. Proc. 2002 National Meeting of the Canadian Weed Science Society. [Online]. Available: http://www.cwss-scm.ca [13 July 2005]. 
Thomas, P. 2001. Outcrossing between canola varieties - a volunteer canola control issue. [Online]. Available: http://www1.agric.gov.ab.ca/\$department/deptdocs.nsf/all/crop1300 [6 September 2005].

Van Acker, R. C., Brûlé-Babel, A. L., Friesen, L. F. and Entz, M. H. 2003. GM/non-GM wheat co-existence in Canada. Roundup Ready ${ }^{\circledR}$ wheat as a case study. Pages 60-68 in B. Boelt, ed. Proc. 1st European Conference on the Co-existence of Genetically Modified and Conventional and Organic Crops. Danish Institute of Agricultural Sciences, Research Centre, Flakkebjerg, Denmark.

Warwick, S. I. 2005. Past/future research perspective from Canada: living with GM crops in agriculture. Gene Flow in Plants and Microorganisms Initiative Workshop, Biotechnology and Biological Sciences Research Council (BBSRC). 23-24 June 2005 Symposium Abstract, London UK.

Warwick, S. I., Beckie, H. J., Simard, M-J., Légère, A., Nair, H. and Séguin-Swartz, G. 2004. Environmental and agronomic consequences of herbicide-resistant (HR) canola in Canada. Pages 323-337 in Introgression from genetically modified plants (GMP) into wild relatives. H. C. M. den Nijs, D. Bartsch and J. Sweet, eds. CABI Publ., Wallingford, Oxfordshire, UK.

Warwick, S. I., Beckie, H. J. and Small, E. 1999. Transgenic crops: new weed problems for Canada? Phytoprotection 80: 71-84.

Warwick, S. I., Simard, M.-J., Légère, A., Beckie, H. J., Braun, L., Zhu, B., Mason, P., Séguin-Swartz, G. and Stewart, C. N. 2003. Hybridization between transgenic Brassica napus L. and its wild relatives: Brassica rapa L., Raphanus raphanistrum L., Sinapis arvensis L., and Erucastrum gallicum (Willd.) O. E. Schulz. Theor. Appl. Genet. 107: 528539. 
Table 1. Transgenic ${ }^{\mathrm{z}}$ crops grown from 2003 to 2005, listed by country, trait, and crop [adapted from James $(2003,2004,2005)]$.

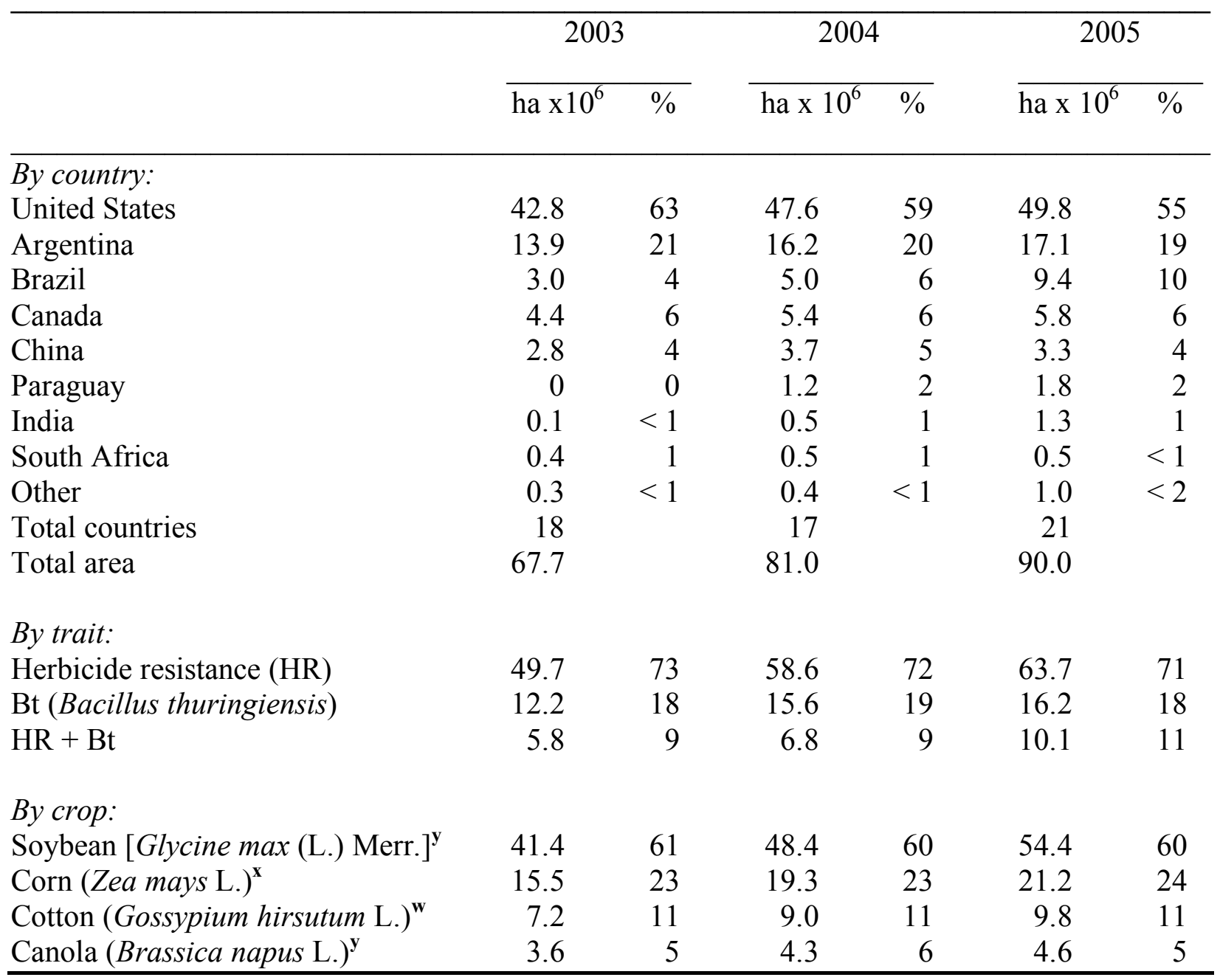

${ }^{\mathrm{z}}$ Imidazolinone-HR crops excluded.

${ }^{\mathbf{y}}$ All HR.

${ }^{\mathrm{x}} \mathrm{HR}=6.4$ million ha $(9 \%)$ in $2003,8.1$ million ha $(10 \%)$ in 2004 , and 9.9 million ha $(11 \%)$ in 2005.

${ }^{\mathrm{w}} \mathrm{HR}=4.1$ million ha (6\%) in 2003 and 4.9 million ha (5\%) in 2005 (2004 data not available). 
Table 2. Herbicide-resistant field crops registered in Canada, and weediness in cropped land, non-cropped disturbed areas (including roadsides and waste ground), and natural areas [adapted from Beckie et al. (2001b)].

\begin{tabular}{|c|c|c|c|c|c|c|c|}
\hline \multirow[b]{2}{*}{ Species } & \multirow[b]{2}{*}{$\begin{array}{l}\text { Herbicide } \\
\text { resistance }\end{array}$} & \multirow[b]{2}{*}{$\begin{array}{l}\text { Variety } \\
\text { registration }\end{array}$} & \multirow[b]{2}{*}{$\begin{array}{l}\text { Regulatory } \\
\text { approval }\end{array}$} & \multirow[b]{2}{*}{$\begin{array}{l}\text { Breeding } \\
\text { system }\end{array}$} & \multicolumn{3}{|c|}{ Weediness } \\
\hline & & & & & $\begin{array}{l}\text { Crop- } \\
\text { land }\end{array}$ & $\begin{array}{l}\text { Disturbed } \\
\text { areas }\end{array}$ & $\begin{array}{c}\text { Natural } \\
\text { areas }\end{array}$ \\
\hline $\begin{array}{l}\text { Canola, } \\
\text { Brassica napus }\end{array}$ & $\begin{array}{l}\text { Glyphosate } \\
\text { Glufosinate } \\
\text { Imidazolinone } \\
\text { Bromoxynil }\end{array}$ & $\begin{array}{l}\text { Yes } \\
\text { Yes } \\
\text { Yes } \\
\text { Yes }\end{array}$ & $\begin{array}{l}\text { Yes } \\
\text { Yes } \\
\text { Yes } \\
\text { Yes }\end{array}$ & $\begin{array}{l}\text { ca. } 30 \% \\
\text { outcrossing }\end{array}$ & Yes & Yes & No \\
\hline $\begin{array}{l}\text { Soybean, } \\
\text { Glycine } \max \end{array}$ & $\begin{array}{l}\text { Glyphosate } \\
\text { Glufosinate }\end{array}$ & $\begin{array}{l}\text { Yes } \\
\text { No }\end{array}$ & $\begin{array}{l}\text { Yes } \\
\text { Yes }\end{array}$ & $\begin{array}{l}\text { Highly } \\
\text { selfing }\end{array}$ & Rarely & No & No \\
\hline $\begin{array}{l}\text { Corn, } \\
\text { Zea mays }\end{array}$ & $\begin{array}{l}\text { Glyphosate } \\
\text { Glufosinate } \\
\text { Imidazolinone } \\
\text { Sethoxydim }\end{array}$ & $\begin{array}{l}\mathrm{NA}^{\mathbf{z}} \\
\mathrm{NA} \\
\mathrm{NA} \\
\mathrm{NA}\end{array}$ & $\begin{array}{l}\text { Yes } \\
\text { Yes } \\
\text { Yes } \\
\text { Yes }\end{array}$ & $\begin{array}{l}\text { Highly } \\
\text { outcrossing }\end{array}$ & Yes & No & No \\
\hline $\begin{array}{l}\text { Wheat, } \\
\text { Triticum aestivum }\end{array}$ & Imidazolinone & Yes & Yes & $\begin{array}{l}\text { Highly } \\
\text { selfing }\end{array}$ & Yes & No & No \\
\hline
\end{tabular}

${ }_{\mathrm{Z}}^{\mathrm{NA}}$ : not required. 
Table 3. Average seed yield ( $\left.\mathrm{t} \mathrm{ha}^{-1}\right)$ advantage of non-herbicide-resistant (HR) soybean compared with glyphosate-HR soybean from public variety trials in Ontario, 2002-2004 [adapted from OOPSCC (2005)].

\begin{tabular}{lccc}
\hline Heat unit zone & Glyphosate-HR & Non-HR & $\begin{array}{c}\text { Non-HR yield } \\
\text { advantage (\%) }\end{array}$ \\
\hline 2400 & 3.18 & 3.28 & 3.1 \\
2600 & 3.14 & 3.28 & 4.5 \\
2800 & 3.60 & 3.77 & 4.7 \\
3100 (clay) & 2.63 & 2.82 & 7.2 \\
3100 (loam) & 3.63 & 3.75 & 3.3 \\
3400 (clay) & 3.00 & 3.09 & 3.0 \\
3400 (loam) & 3.69 & 3.86 & 4.6 \\
\end{tabular}

${ }^{\mathrm{z}}$ Trial sites with a clay or loam soil texture in 3100 and 3400 heat unit zones.

Table 4. Average yield index (percentage of the mean of all cultivars) ${ }^{\mathrm{z}}$ of glyphosate-herbicideresistant (HR), glufosinate-HR and non-HR corn hybrids from variety trials in Ontario in 2004 [adapted from Ontario Corn Committee (2005)] $]^{\mathrm{z}}$.

\begin{tabular}{llll}
\hline Heat unit zone & Glyphosate-HR & Glufosinate-HR & Non-HR
\end{tabular}

\begin{tabular}{lrrr}
\hline & & & \\
$2400-2600$ & 100 & 93 & 102 \\
$2550-2750$ & 101 & 100 & 100 \\
$2700-2900$ & 100 & 100 & 100 \\
$2850-3050$ & 101 & 100 & 100 \\
$3000-3200$ & 95 & 101 & 100 \\
$3200-3450$ & NA $^{\mathbf{y}}$ & 99 & 100 \\
\hline
\end{tabular}

\footnotetext{
${ }^{\mathrm{z}}$ Index values above 100 indicate the percentage by which a hybrid system is above the average; values below 100 indicate the percentage below the average.

${ }^{\mathbf{y}} \mathrm{NA}$ - no glyphosate-HR hybrids.
} 